\title{
CORPORATE AND INDIVIDUAL INCOME TAX INTEGRATION IN THE UNITED STATES DURING THE 1990s
}

\begin{abstract}
The United States Federal Income Tax laws continue to employ the socalled "classical system" which treats corporations and their investors as separate taxable entities and imposes tax at both the corporate and shareholder levels on earnings that are distributed by the corporation as dividends. There is no relief from this double tax on individual shareholders. Dividends are not deductible by the corporation. In contrast, corporate earnings that are distributed to lenders as interest are deductible by the corporation and taxable to the lender. Investors who choose non-corporate forms of business, such as the sole proprietorship or partnership, or closely-held corporations that qualify to elect to be taxed as " $S$ Corporations" (formerly known as Subchapter S Corporations), are taxed on a pass-through method and the undistributed as well as distributed earnings of the business are taxable, currently, to the shareholders, at their rates and according to their relevant individual tax characteristics. For the ordinary corporation, however, the corporate income tax is not "integrated" with the individual income tax.
\end{abstract}

For years arguments have been raised in favor of "integrating" the corporate and individual income taxes in the United States. It is claimed that the United States unintegrated, classical system, by imposing a double layer of tax on distributed corporate earnings, discriminates against the choice of the corporation as a form of business entity, discriminates in favor of interest as distinguished from dividends and hence encourages "thin capitalization" and excessive use of debt finance, encourages the retention of corporate earnings, and rewards their eventual distributions in forms that are not taxable as ordinary dividends, causes under-financing of the corporate sectors of the economy, taxes corporate income unfairly and contributes to economic inefficiencies and a loss of welfare in the United States, not to mention international competitive disadvantage. The integration movement gathered energy in the late 1970s, but then diminished and was relatively quiet, until the late 1980s. Concern about excessive use of debt and the failure of over-leveraged companies in the late 1980s and the early 1990s revived the question of how to tax corporate earnings distributed either as dividends or as interest, and whether to "integrate" the corporate income tax with the individual income tax. In a country with a low rate of investment, there was

${ }^{1}$ Roger J. Traynor Professor of Law, University of California, Berkeley School of Law (Boalt Hall). Copyright 1990, 1993, John K. McNulty. 
concern that the historical system discouraged new equity financing of corporate investments.

On January 6, 1992, the U.S. Treasury Department issued a report entitled "Integration of the Individual and Corporate Tax Systems, Taxing Business Income Once." This report results from the revival of the debate, and help set the agenda for the policy discussion in the ensuing year. The Secretary of the Treasury had been instructed by the Tax Reform Act of 1986 to study reforms of the taxation of corporate income. It was earlier expected that the study would consider less fundamental approaches to corporate income tax reform. The Treasury decided to undertake a more comprehensive study of integration of the corporate and individual tax and to address fundamental questions about how the corporate income tax might be restructured to reduce tax distortions of important corporate financial decisions and to achieve a more efficient system, especially given the prevalence of integrated corporate income tax systems elsewhere in the world.

During the preceding year, the prestigious American Law Institute also was beginning to undertake a study of integrating the corporate and individual income taxes. By October of 1992, a draft of the ALI "Reporter's Study" on "Integration of Individual and Corporate Income Taxes" was made available to the Council of the American Law Institute. (Earlier drafts had been discussed by special study groups and consultants to the American Law Institute.)

The American Law Institute "Reporter's Study" proposed a shareholder imputation credit method of integration of the corporate and individual income tax for the United States in a form resembling that recently enacted in New Zealand, and familiar in Australia and the European Community. Under this method of integration, the corporate income tax would remain in place, and dividends would be taxable to shareholders, but the shareholders would receive a credit for the corporate tax paid with respect to the earnings out of which distributions were made to them as dividends. The ALI Reporter, Prof. Alvin Warren of the Harvard Law School, produced an excellent analysis and proposal for shareholder imputation credit integration in the United States, thoughtfully argued and superbly worked out, although not cast in the form of legislation. The ALI proposal benefitted from the work of the "Carter Commission" of Canada, the Royal Commission which produced an attractive proposal for shareholder credit integration in 1966, including a plan for voluntary "allocation" of retained earnings. In the United States, the rate relationships newly established by the 1986 Tax Reform Act, relationships between the top individual income tax rate and the top corporate income tax, made the Carter Commission "allocation" idea, and the shareholder credit method of integration in general, especially feasible and desirable in the United States. Taking into account the experience and legislative variations among shareholder credit integration systems in Western Europe and the rest of the world, the ALI study could look forward to attention by policy analysts and the Congress of the United States.

Somewhat surprisingly, the Treasury Department's study issued in January 1992 did not recommend, or prefer, the shareholder imputation credit method. The Treasury study outlined four prototypes for integration. One of these was the 
imputation credit prototype, but the Treasury recommended against such integration for the United States system. It also recommended against a dividend deduction alternative.

The Treasury study concentrated on three other integration prototypes. The first was a simple proposal to exclude dividends from the income taxable to shareholders, the "dividend-exclusion prototype." The second was a "shareholder allocation" model, much like the partnership or transparency models discussed in many countries over the years, and rather like the "Subchapter $S$ " legislation in the United States, under which corporate earnings would be allocated to shareholders, even though not distributed to them, and would be taxable to them, either without a tax at the corporate level, or with a credit for tax paid at the corporate level. The Treasury Department recommended against that approach as well. The final prototype was the "Comprehensive Business Income Tax" or "CBIT" prototype. The CBIT model would impose a schedular or flat rate of tax on business earnings not only upon the income of corporations but also upon the income of partnerships, proprietorships, and all other businesses or business associations. Distributions by such entities to shareholders or other investors would be excluded from income, much as dividends would be excluded under the dividend exclusion prototype. Most remarkably, the CBIT proposal would deny a deduction at the business level for interest, and would exclude interest from the income of recipients, just the way dividends would be excluded from the income of shareholders. Interest and dividends, both viewed as costs of capital, would be treated alike.

As Treasury recognized, the dividend exclusion model would be relatively simple to legislate and put into place, whereas, the CBIT proposal represented a long-term and more comprehensive method of taxing all business associations similarly, and equalizing the tax treatment of debt and equity. Treasury suggested that full implementation of CBIT might well take ten years to bring into effect, by a series of phases. Unlike the other proposals for integration, the CBIT proposal would be "self-financing," and in fact would generate additional revenue, which would permit lowering the corporate rate to the same level as the maximum individual income tax rate of $31 \%$, without loss of revenue, even if capital gains on corporate stock were fully exempt from tax when realized by shareholders.

The Treasury Department made a number of policy recommendations, which then unfortunately acted as constraints on their study. These included the ideas that (i) integration should not result in the extension of corporate tax preferences to shareholders, (ii) integration should not reduce the total tax collected on corporate income allocable to tax-exempt investors, (iii) integration should be extended to foreign shareholders only through treaty negotiations, not by statute, and finally (iv) that foreign taxes paid by U.S. corporations should not be treated by statute identically to taxes paid to the United States government.

Throughout 1992, scholarly tax thinkers and expert groups studied the Treasury proposal and the American Law Institute proposal, evaluating the merits of each, and laying the foundation for conversion of one or more of the proposals to legislative form. The United States Treasury Department promised that before 
the end of 1992, it would make a legislative recommendation and thus express a choice of which form of integration should be adopted.

In a December 11, 1992 letter from Treasury Secretary Nicholas F. Brady to House Ways and Means Committee Chairman Dan Rostenkowski, the Treasury Department enclosed its recommendation. This recommendation is very similar to the dividend-exclusion prototype first put forward by Treasury on January 6 , 1992. In other words, Treasury preferred the dividend exclusion approach to a pass-through or shareholder imputation credit model, and also it preferred the simple dividend-exclusion approach to the more comprehensive "comprehensive business tax" approach that was the strongest recommendation made in January by the Treasury Department. It preferred the dividend exclusion approach because of its simplicity, because it could be relatively easily inserted into the present legal framework of the corporate income tax and easily administered, and could be implemented at once, without any transition or phase-in period. Also, Treasury stated that the dividend-exclusion approach was preferable to the shareholder allocation and to the imputation-credit prototypes because it is consistent with Treasury's policy view that, over the long term, it would be desirable to move the tax system in the direction of a schedular tax on enterprise activity, a tax like the CBIT prototype or some version of a business cash flow tax or a business transfer $\operatorname{tax}$.

Under the dividend exclusion model recommended on December 11, 1992, a corporation must compute its taxable income and pay tax as under current law. Any distribution made to shareholders out of the corporation's income that remained after paying its tax and after making certain limited adjustments to "taxable income," adjustments that would produce the determination of "adjusted taxable income" or "ATI," would be treated as a dividend and would be excludable from gross income when received by the shareholders. Distributions in excess of ATI would be treated as a return of capital to the shareholders, or capital gain to the extent the distributions exceeded their adjusted bases in their shares. (A shareholder's basis in the shares is a changing record of the shareholders after-tax dollar or "capital" invested in the shares, not previously returned by corporate distributions or tax benefits.)

ATI (adjusted taxable income) is defined by this new Treasury proposal as corporate taxable income that has been reduced by Federal income taxes and creditable foreign taxes paid or accrued, and increased by excludable dividends received and by any items of income that are permanently excluded from income under the present tax law (tax-exempt interest, percentage depletion in excess of basis, etc.). Because distributions that exceed taxable income are to be treated as a return of capital to the shareholders, no distribution is ever treated as a taxable dividend to shareholders. That is to say, a distribution is either an excludable dividend, up to ATI, or is a return of capital or produces capital gain to the extent the distribution exceeds each shareholder's basis in his or her shares, capital gain which is taxable under the American system at rates that sometimes differ from the rates applicable to ordinary income.

The new Treasury proposal allows corporations to adopt a "dividend reinvestment plan" (unfortunately termed a "DRIP"), along the lines of the 
dividend reinvestment plan proposed by Treasury in January of 1992, and modeled on the "voluntary allocation" of the Carter Commission report in Canada in 1966. Under the dividend reinvestment plan, a corporation voluntarily could pretend that a cash dividend had been paid to its shareholders out of its adjusted taxable income and that such dividend was immediately reinvested by the shareholders. In other words, no money would change hands, and cash would not be distributed to shareholders who would then actually return it to the corporation. Instead, earnings of the corporation retained by the company would be "deemed" to have been distributed and recontributed. The shareholders would not pay any tax on the constructive or "deemed" dividend (because all dividends are excludable by shareholders), but they would increase their bases in their shares by the amount of the "deemed" dividend. The effect of this basis increase would be to reduce the capital gain, or increase any capital loss, that the shareholders would realize when they sell their shares. The gain would be reduced by an amount equal to the corporation's retained but previously taxed and "allocated" earnings.

The ATI proposal of Treasury on December 11, 1992 differs in some important respects from the dividend exclusion prototype described earlier by Treasury in its integration study of January, 1992. The most important differences are the following: First, all distributions in excess of "adjusted taxable income" are treated as returns of capital to the shareholders, rather than as taxable dividends. Secondly, integration is extended to foreign source income, by "flowing through" creditable foreign taxes. Thirdly, the proposal would have an immediate effective date with only limited, elective transition relief for corporate shareholders. Like the dividend-exclusion proposal of January, the ATI proposal would not be extended to foreign shareholders by statute, but Treasury contemplated that integration benefits might be granted to foreign shareholders by international income tax treaties.

The December 1992 Treasury proposal contained 23 recommendations. These recommendations constitute the ATI proposal itself. Some of them are relatively technical and explain the extent to which the proposal would allow the present corporate income tax to remain in place without modification, and others indicate that some, relatively minor, alterations would have to be made in the corporate tax legislation.

One of the Treasury recommendations indicates that the current United States' treatment of "S Corporations" (formerly "Subchapter S Corporations"), partnerships and other pass-through entities, such as regulated investment companies, real estate investment trusts and real estate mortgage investment conduits, would be retained. This would mean that investors who would prefer to have a single layer of tax imposed on business eamings at the rates dictated by the individual income tax and by the income tax situations of the shareholders, could, subject to eligibility rules, form proprietorships or partnerships or other pass-through entities, or could cause their closely-held corporations, if otherwise qualified, to elect "Subchapter S" treatment. While the top individual rates of income tax in the United States are now $31 \%$ and the top corporate rate is $34 \%$, it seems quite likely that rate increases in one or both taxes will be enacted in the 
future, at least within some income ranges as President Clinton has proposed, and that the relatively equivalent relationship between the top rates, and the lower or intermediate rates, would cease to exist. If, for example, individual rates went far higher than the corporate rates, taxpayers might prefer to use a corporation subject to the new ATI proposal, because the business income would be taxed once, at corporate rates, and not taxed a second time, even upon distribution to high-income shareholders. On the other hand, if top corporate rates went higher than top individual income tax rates, or the rates applicable to particular shareholders, investors might prefer the pass-through treatment of partnerships and $S$ Corporations, because that would mean one level of tax, at the individual shareholder rate, rather than the higher corporate rate. If taxpayers anticipate losses in their business, they might prefer the pass-through treatment of partnership or S Corporation form, which would allow those losses to be deducted from other income on their individual shareholder retums.

Treasury recognized that retaining Subchapter $S$ and partnership treatment is somewhat inconsistent with its long-term policy preference for a schedular tax on enterprise activity and with its goal of tax simplification. It recognized however that the partnership, Subchapter $S$ and other alternative regimes are so deeply embedded in the U.S. income tax system that any other approach would prove exceedingly disruptive and would require elaborate transition rules. Treasury implied that conversion to a Comprehensive Business Income Tax (CBIT) later would be desirable and would entail repealing Subchapter S.

There follows a commentary on the subject of integrating the corporate and individual income taxes in the United States. This was written and published in the U.S. before the 1992 A.L.I. and Treasury proposals were published. It argues for a form of integration generally like that employed in many industrialized countries of the world, with a particular feature (voluntary "allocation" of undistributed earnings like that recommended for Canada by the Carter Commission in 1966), because of the hospitable income tax rate relationships in effect in the United States after 1986. The A.L.I. proposal resembles the proposal recommended here. The January and December 1992 Treasury proposals recommend a different method of integration. The income tax rate increases suggested by President Clinton in his February 1992 address to the U.S. Congress do maintain the rate relationships that make imputation-credit integration with Carter-type voluntary allocations an excellent policy choice for the United States. However, the large budget deficits will make it difficult to succeed with any integration proposal that entails a revenue loss for the U.S. Treasury.

The commentary that follows is pertinent now in recommending that Congress should not adopt the U.S. Treasury proposals, but should instead follow the American Law Institute's policy choice and that doing so would fit the U.S. tax system better into the integration systems adopted in many countries of Western Europe, Australia and New Zealand. 